\title{
ECOLOGY
}

\section{Use of food resources and resource partitioning among five syntopic species of Hypostomus (Teleostei: Loricariidae) in an Atlantic Forest river in southern Brazil}

\author{
Vinicius Abilhoa ${ }^{1,}{ }^{*}$, Marcos O. Valduga ${ }^{2}$, Fabricio de A. Frehse ${ }^{2} \&$ Jean R.S. Vitule ${ }^{3}$ \\ ${ }^{1}$ Grupo de Pesquisas em Ictiofauna, Museu de História Natural Capão da Imbuia. Rua Prof. Benedito Conceição \\ 407, 82810-080 Curitiba, PR, Brazil. \\ 2Programa de Pós-Graduação em Ecologia e Conservação, Setor de Ciências Biológicas, Universidade Federal do \\ Paraná, Curitiba, PR, Brazil \\ ${ }^{3}$ Laboratório de Ecologia e Conservação, Departamento de Engenharia Ambiental, Setor de Tecnologia, \\ Universidade Federal do Paraná, Curitiba, PR, Brazil. \\ *Corresponding author. E-mail: vabilhoa@uol.com.br
}

\begin{abstract}
We analyzed the diet and resource partitioning among five syntopic species of Hypostomus Lacépède, 1803 in the Corumbataí River in southeastern Brazil. The gut contents of 352 individuals were assessed and 21 food items were identified and quantified under an optical microscope. The food items found in the gut contents indicate that these suckermouth loricariids are bottom-dwelling detritivorous/periphytivorous catfishes. PERMANOVA and SIMPER analyses indicated variation in the consumption of some resources, and the contribution of periphytic algae was primarily responsible for such dissimilarity. ECOSIM analyses of dietary overlap showed evidence of resource sharing among all species in the dry and rainy periods. This is most likely the result of the predominance of detritus and autochthonous items such as algae and aquatic immature insects in all gut contents. Our data suggest that trophic resources available in the Corumbataí River are explored and partitioned among Hypostomus species, all specialized in surface-grazing foraging behaviour.
\end{abstract}

KEY WORDS. armoured catfish, feeding, food overlap, periphyton, Siluriformes.

The suckermouth armored catfishes of the genus Hypostomus Lacépède, 1803 are bottom-dwelling loricariids. They are characterized by certain morphological specializations such as outstanding structural modifications on the feeding apparatus (Schaefer 1987) and shape of the intestine (Podkowa \& GoniaKOWSKA-WITALIŃSKA 2003). The ventrally oriented oral disc with adhesive papillae and comb-like tooth plates of the upper and lower jaws, depressed body and paired fin orientation are morphological adaptations to fast flowing aquatic environments (Burgess 1989). These adaptations allow them to strongly adhere to and scrap uneven and structurally complex substrates (SCHAEFER \& LAUder 1986).

Although many armored catfishes normally feed on algae growing on submerged surfaces (Buck \& SAZIMA 1995, PAGotTo et al. 2011, POWER 1984), studies on the diet of Hypostomus indicate that they can also feed on detritus and other small food items (Cardone et al. 2006, Delariva \& Agostinho 2001, Mazzoni et al. 2010). This typically benthic feeding habit has important effects on primary production, nutrient cycling and macro invertebrates drift, among other direct and indirect ecological effects (DUDGEON 1993, FAusch et al. 2002, McInTyre et al. 2007).

In the Neotropical region, several studies analyzed the relationships between armored catfishes with similar morphological characteristics and feeding ecology (e.g., Delariva \& Agostinho 2001, Casatti \& Castro 2006, Ferreira 2007, Pagotto et al. 2011), showing the influence of adaptive variations in the feeding-mode on the segregation of trophic niches, with important consequences for resource utilization and interactions among coexisting species (Delariva \& Agostinho 2001).

The coexistence of functionally similar species can be promoted through differential use of resources. Resource partitioning includes food, habitat and/or temporal segregation (e.g., PiANKa 1973, SCHOENer 1974, Ross 1986), and has been extensively documented among Neotropical fishes (e.g., Winemiller 1989, Jepsen et al. 1997, Merona \& Rankin-De-Merona 2004, Silva et al. 2012). The degree of overlap in the use of available resources among sympatric, similar species is variable, and interactions are associated, for example, with seasonal and/or spatial fluctu- 
ations (Winemiller et al. 2008), ontogenetic variations (Frehse et al. 2015), and competition (FAUSCH et al. 2002). The availability and use of resources play an important role in regulating the biomass, the structure and functioning of the fish community and ecosystem (FAusch et al. 2002, Winemiller et al. 2008), and contribute to the maintenance of the high functional and taxonomic diversity of the Neotropical ichthyofauna.

In this study we examined patterns of food utilization of five syntopic species of Hypostomus, which are common and abundant inhabitants of lotic aquatic ecosystems in the Neotropical region. Despite the influence of seasonal changes (Dry or Rainy seasons), we expected that the overlap in the diet of those species would be substantial since they are morphologically similar. Specifically, we attempted to determine whether information on diet and feeding overlap could throw a light on how the available resources are exploited.

\section{MATERIAL AND METHODS}

This study was conducted in the Corumbataí River $\left(24^{\circ} 14^{\prime} \mathrm{S}\right.$ and $\left.51^{\circ} 56^{\prime} \mathrm{W}\right)$, in a stretch of approximately $20 \mathrm{~km}$. In this stretch, the river is very homogenous in its general characteristics. There are no artificial and natural barriers (e.g. waterfalls, dams), the average depth is $0.62 \mathrm{~m}$, the average channel width is $26 \mathrm{~m}$, the canopy cover is $25 \%$, the river velocity is $17 \mathrm{~m} \mathrm{~s}^{-1}$, and the substrate consists mainly of sand, gravel and rocks. All adjacent regions are surrounded by agriculture and livestock. The Corumbataí River flows into the Ivaí River, a tributary of the left bank of the upper Paraná River, which has a drainage area of $36,899 \mathrm{~km}^{2}$ and extends for approximately $675 \mathrm{~km}$. It is located in the aquatic ecoregion known as the Upper Paraná, with a reported richness of 310 species and many endemic catfishes (LANGEANI et al. 2007).

The climate in our study region is subtropical (CAvigLIONE et al. 2000) with the temperature ranging from $22^{\circ} \mathrm{C}$ during the warmer months to $18^{\circ} \mathrm{C}$ during the colder months. This region enjoys a regular amount of evenly distributed rainfall, but during our sampling period the rain volume was one of the lowest recorded in the history of the last 50 years (IAPAR 2015). The dry season (March-August 2006) was defined based on the average monthly precipitation, which was $49 \mathrm{~mm}$. The rainy season (September 2006 to February 2007) had an average monthly precipitation of $207 \mathrm{~mm}$. These conditions were used in the analysis of the seasonal variation in the diet of the fish assemblage.

Monthly samples were collected between March 2006 and February 2007, using gillnets placed parallel to the riverbank for 24 hours and a seine net operated for a period of 10 minutes. After capture, all fish were fixed in $4 \%$ formaldehyde and after five days they were transferred to 70\% alcohol. In the laboratory, individuals were identified, labelled, weighed (total weight, kg), measured (standard length, $\mathrm{mm}$ ) and dissected for the removal of the gut contents. Voucher specimens of Hypostomus ancistroides Ihering, 1911, H. strigaticeps Regan, 1908, H. commersoni Valen- ciennes, 1836, H. hermanni (Ihering, 1905), and Hypostomus sp. were deposited in the fish collection of the Museu de História Natural Capão da Imbuia (MHNCI 12355-MHNCI 12359).

Food contents were identified to the lowest feasible taxonomical level and quantified using a compound light microscope following a specific methodology based on ARANHA (1993). After the extraction of the contents of the anterior third of the digestive tract, the material was homogenized and three slides (subsamples) were prepared. The slides were placed on the stage of the microscope and moved to a random location. This random location was defined using the numbering system present on the mechanical stage using one dimension as the abscissa and the other as the ordinate. The field determined by the ordinate and the abscissa $(1 \times 1 \mathrm{~mm})$ was analysed at 200 and 400 times magnification. A minimum of seven and a maximum of 10 locations per slide were analysed, totalling an average of 25 locations per stomach content. Items were quantified according to their percentage contributions. The frequency of occurrence and percentage contribution methods were used in the diet analysis (HyNes 1950).

Differences in diet composition were investigated through permutational multivariate analysis of variance (PERMANOVA), and similarity percentage analysis (SIMPER) methods performed by the Primer v6 software (Clarke \& GORLEy 2006), using stomachs as samples and seasons (Dry or Rainy) and species as fixed factors. A similarity matrix was constructed using the Bray-Curtis index, using the transformed $(\log X+1)$ values of the percentage contribution of food items. This matrix was subjected to a two-way PERMANOVA analysis (ANDERSON et al. 2008) in order to examine the effects of the factors (seasons and species) on the diet composition. Significant factors were further analyzed using a PERMANOVA pairwise comparison. All tests utilized Bray-Curtis dissimilarity as the metric and were permutated 9,999 times under a reduced model.

Percentage Contribution Analysis (SIMPER) was carried out (CLARKE \& GORLEY 2006) in order to estimate the contribution of each variable (food item) to the observed similarity or dissimilarity between samples. It was, therefore, useful in assessing the importance of the different food items to the overall diet, and in identifying the variables that are more important in creating the observed pattern of similarity.

Diet overlaps in each season between all pairs of Hypostomus species were calculated through the Pianka index (PIANKA 1973) in the software EcoSim, version 7.72 (GOTELLI \& ENTSMINGER 2000). This measure of overlap is symmetrical and assumes values ranging from 0 (no prey in common between two species) to 1 (species share the same relative amount of food items), and the overlap is considered high when values exceed 0.60 (sensu WaLlaCe 1981). Niche overlaps among Hypostomus species in each season were statistically tested against null models (RA3 algorithm, 1,000 iterations) using the EcoSimR package (GotelLI et al. 2015) with R 3.3.1 statistics software (R Development Core TEAM 2016), in order to evaluate whether the pattern of niche overlap diverged significantly from a random distribution (absence of overlap). 


\section{RESULTS}

A total of 352 individuals of Hypostomus ancistroides, $H$. strigaticeps, H. commersoni, H. hermanni, and Hypostomus sp. were captured, with a total weight of $19.39 \mathrm{~kg}$. In both seasons there was an overlap in the sizes (SL) of all Hypostomus species. The two most common species (H. commersoni and Hypostomus sp.) comprised $75.8 \%$ of all captures and $66.8 \%$ of total biomass. No taxon was exclusive to the samples collected in the dry or rainy seasons, and H. commersoni and Hypostomus sp. were the most abundant in both periods (Table 1 ).

Table 1. Number of individuals $(\mathrm{N})$, standard length $(\mathrm{SL})$ variation (range, mean and SD = standard deviation, $\mathrm{mm}$ ), and total biomass (WG, kg) registered for the loricariids captured from the Corumbataí River in the dry and rainy seasons.

\begin{tabular}{lccccccccc}
\hline \multirow{2}{*}{\multicolumn{1}{c}{ Species }} & \multicolumn{4}{c}{ Rainy } & \multicolumn{5}{c}{ Dry } \\
\cline { 2 - 9 } & N & SL range & SL mean \pm SD & WG & N & SL range SL mean \pm SD & WG \\
\hline H. ancistroides & 10 & $119-200$ & $18.21 \pm 3.07$ & 1.22 & 20 & $132-180$ & $17.33 \pm 3.68$ & 1.83 \\
H. commersoni & 69 & $101-170$ & $13.81 \pm 2.43$ & 3.21 & 86 & $98-259$ & $13.91 \pm 2.79$ & 3.61 \\
H. hermanni & 13 & $98-152$ & $14.73 \pm 2.79$ & 0.86 & 9 & $105-175$ & $13.48 \pm 2.71$ & 0.32 \\
Hypostomus sp. & 57 & $97-151$ & $14.01 \pm 2.25$ & 3.12 & 69 & $78-145$ & $13.28 \pm 2.51$ & 3.03 \\
H. stigatriceps & 6 & $138-214$ & $20.19 \pm 4.92$ & 1.03 & 13 & $120-177$ & $17.21 \pm 2.56$ & 1.16 \\
\hline
\end{tabular}

The results on diet composition of gut contents included 21 different food items (Table 2). In general, the diet of all Hypostomus species was slightly more diverse during the rainy than the dry season. In the dry season, immature aquatic stages of Coleoptera, Odonata nymphs, rotifers and gastropods were absent from the diet of all species.

The PERMANOVA analysis revealed differences in resource use by species (Pseudo-F $=6.61, \mathrm{p}<0.001$ ) and season (Pseudo-F $=8.04, \mathrm{p}<0.001$ ) (Table 3). Pairwise tests found differences between $H$. ancistroides and $H$. commersoni, Hypostomus sp., $H$. stigatriceps; H. commersoni and Hypostomus sp.; H. hermanni and Hypostomus sp.; Hypostomus sp. and H. stigatriceps. The diet of $H$. ancistroides, Hypostomus sp., and H. stigatriceps were also found to vary significantly between seasons (Table 4 ).

SIMPER analysis showed that the similarities among the diets of Hypostomus species' result from the high percentage contribution of detritus, diatoms and algae fragments, and that the dissimilarity between the diets of $H$. ancistroides and H. commersoni, Hypostomus sp. and H. stigatriceps, and between

Table 3. Results of the two-way crossed PERMANOVA analysis on the use of food resources, considering the factors season and species. (df) Degree of freedom, (SS) Sum of squares, (MS) Mean sum of squares, (Pseudo-F) Statistic, P (perm) Probability.

\begin{tabular}{lrrrrrc}
\hline \multicolumn{1}{c}{ Factor } & df & \multicolumn{1}{c}{ SS } & MS & Pseudo-F & P (perm) & $\begin{array}{c}\text { Permutations } \\
\text { performed }\end{array}$ \\
\hline Season & 1 & 3243.3000 & 3243.30 & 8.04 & $<0.001^{*}$ & 9942 \\
Species & 4 & 10657.0000 & 2664.20 & 6.61 & $<0.001^{*}$ & 9917 \\
Season x Species & 4 & 5712.0000 & 1428.00 & 3.54 & $<0.001^{*}$ & 9922 \\
Res & 342 & $1.38 \mathrm{E} 5$ & 403.49 & & & \\
Total & 351 & $1.56 \mathrm{E} 5$ & & & & \\
\hline
\end{tabular}

* Indicates the significant results.

Table 2. Relative frequency (FR\%) and frequency of occurrence (FO\%) of food items consumed by: (ANC) Hypostomus ancistroides, (COM) H. commersoni, (HER) H. hermanni, (HSP) Hypostomus sp. and (STR) H. strigaticeps.

\begin{tabular}{|c|c|c|c|c|c|c|c|c|c|c|c|c|c|c|c|c|c|c|c|c|}
\hline \multirow{3}{*}{$\begin{array}{c}\text { Season } \\
\text { Species } \\
\text { Food items }\end{array}$} & \multicolumn{10}{|c|}{ Rainy } & \multicolumn{10}{|c|}{ Dry } \\
\hline & \multicolumn{2}{|c|}{ ANC } & \multicolumn{2}{|c|}{ COM } & \multicolumn{2}{|c|}{ HER } & \multicolumn{2}{|c|}{ HSP } & \multicolumn{2}{|c|}{ STR } & \multicolumn{2}{|c|}{ ANC } & \multicolumn{2}{|c|}{ COM } & \multicolumn{2}{|c|}{ HER } & \multicolumn{2}{|c|}{ HSP } & \multicolumn{2}{|c|}{ STR } \\
\hline & FR\% & $\mathrm{FO} \%$ & FR\% & $\mathrm{FO} \%$ & FR\% & $\mathrm{FO} \%$ & $\mathrm{FR} \%$ & $\mathrm{FO} \%$ & $\mathrm{FR} \%$ & $\mathrm{FO} \%$ & $\mathrm{FR} \%$ & $\mathrm{FO} \%$ & $\mathrm{FR} \%$ & $\mathrm{FO} \%$ & FR\% & $\mathrm{FO} \%$ & FR\% & FO\% & FR\% & $\mathrm{FO} \%$ \\
\hline Detritus & 48.8 & 100.0 & 46.4 & 100.0 & 52.9 & 100.0 & 40.4 & 100.0 & 46.1 & 100.0 & 49.0 & 100.0 & 51.1 & 100.0 & 43.1 & 100.0 & 50.1 & 100.0 & 51.2 & 100.0 \\
\hline Cyanophyceae & 0.4 & 68.2 & 0.5 & 63.5 & 0.4 & 72.7 & 0.8 & 78.1 & 0.4 & 66.7 & 0.4 & 50.0 & 0.3 & 52.1 & 0.3 & 55.1 & 0.7 & 73.3 & 0.4 & 40.0 \\
\hline Chlorophyceae & 0.8 & 50.0 & 1.7 & 63.5 & 1.3 & 72.7 & 2.5 & 69.8 & 3.2 & 66.7 & 0.7 & 37.5 & 1.5 & 62.5 & 1.2 & 65.1 & 1.2 & 46.7 & 2.1 & 80.0 \\
\hline Filamentous algae & 0.5 & 36.4 & 3.2 & 55.2 & 0.5 & 59.1 & 5.5 & 91.7 & 5.1 & 77.8 & 1.6 & 37.5 & 2.1 & 66.7 & 0.5 & 58.2 & 2.4 & 76.7 & 4.1 & 70.0 \\
\hline Algae fragments & 21.8 & 100.0 & 27.2 & 99.1 & 27.7 & 100.0 & 26.1 & 6.3 & 23.1 & 100.0 & 12.1 & 87.5 & 26.1 & 100.0 & 32.1 & 100.0 & 18.3 & 100.0 & 20.1 & 100.0 \\
\hline Diatoms & 25.4 & 100.0 & 19.6 & 100.0 & 15.9 & 95.5 & 23.2 & 100.0 & 21.5 & 100.0 & 34.6 & 100.0 & 18.2 & 100.0 & 22.1 & 100.0 & 25.9 & 100.0 & 21.1 & 100.0 \\
\hline Zygnematophyceae & 0.7 & 22.7 & $<0.1$ & 3.7 & - & - & $<0.1$ & 8.3 & - & - & - & - & - & - & - & - & $<0.1$ & 6.7 & - & - \\
\hline Coleoptera larvae & - & - & - & - & 0.3 & 18.2 & - & - & - & - & - & - & - & - & - & - & - & - & - & - \\
\hline Diptera larvae/pupae & 0.2 & 13.6 & $<0.1$ & 4.7 & 0.2 & 18.2 & - & - & - & - & - & - & $<0.1$ & 4.2 & 0.1 & 21.2 & - & - & 0.3 & 20.0 \\
\hline Hemiptera larvae & - & - & - & - & - & - & - & - & - & - & - & - & 0.2 & 2.1 & - & - & - & - & - & - \\
\hline Trichoptera larvae & $<0.1$ & 22.7 & $<0.1$ & 8.4 & $<0.1$ & 18.2 & - & - & - & - & $<0.1$ & 12.5 & $<0.1$ & 10.4 & - & - & - & - & $<0.1$ & 10.0 \\
\hline Odonata nymphs & - & - & $<0.1$ & 2.8 & - & - & - & - & - & - & - & - & - & - & - & - & - & - & - & - \\
\hline Insects remains & 0.5 & 35.5 & 0.2 & 19.6 & 0.3 & 31.8 & $<0.1$ & 11.5 & 0.4 & 33.3 & 0.3 & 37.4 & $<0.1$ & 8.3 & 0.3 & 32.1 & $<0.1$ & 10.0 & 0.2 & 10.0 \\
\hline Free-living nematodes & 0.4 & 36.4 & 0.3 & 56.1 & 0.2 & 45.4 & 0.2 & 23.9 & $<0.1$ & 66.7 & 0.1 & 25.0 & 0.2 & 22.9 & 0.2 & 18.2 & 0.5 & 40.0 & 0.2 & 50.0 \\
\hline Oligochaetes fragments & - & - & - & - & - & - & - & - & - & - & - & - & $<0.1$ & 2.1 & - & - & - & - & - & - \\
\hline Paramecium spp. & - & - & - & - & - & - & $<0.1$ & 4.2 & - & - & - & - & $<0.1$ & 2.1 & - & - & $<0.1$ & 3.3 & - & - \\
\hline Euglena spp. & $<0.1$ & 36.4 & 0.2 & 22.4 & $<0.1$ & 40.9 & 0.3 & 61.5 & $<0.1$ & 44.4 & $<0.1$ & 37.5 & 0.2 & 31.2 & $<0.1$ & 33.2 & 0.3 & 60.0 & $<0.1$ & 40.0 \\
\hline Rotifers & - & - & $<0.1$ & 5.6 & - & - & $<0.1$ & 3.1 & - & - & - & - & - & - & - & - & - & - & - & - \\
\hline Gastropods remains & - & - & - & - & - & - & $<0.1$ & 2.1 & - & - & - & - & - & - & - & - & - & - & - & - \\
\hline Testate amoebae & 0.3 & 22.7 & 0.1 & 17.8 & - & - & 0.2 & 16.7 & - & - & $<0.1$ & 12.5 & $<0.1$ & 12.5 & - & - & $<0.1$ & 16.7 & 0.2 & 30.0 \\
\hline Fish scales & - & - & - & - & - & - & $<0.1$ & 3.1 & - & - & - & - & $<0.1$ & 2.1 & - & - & - & - & - & - \\
\hline
\end{tabular}


Table 4. Pair-wise tests based on PERMANOVA analysis, considering the significant factors in the use of food resources. P (perm) Probability. *Indicates the significant results.

\begin{tabular}{lcll}
\hline \multicolumn{1}{c}{ Grouping factors } & $\mathrm{t}$ & $\mathrm{P}(\mathrm{perm})$ & Permutations performed \\
\hline \multicolumn{1}{c}{ Species vs. Species } & & & \\
\hline H. ancistroides vs. H. commersoni & 2.238 & $0.0007^{*}$ & 9943 \\
H. ancistroides vs. H. hermanni & 1.489 & 0.0521 & 9949 \\
H. ancistroides vs. Hypostomus sp. & 4.113 & $0.0001^{*}$ & 9960 \\
H. ancistroides vs. H. stigatriceps & 2.071 & $0.0007^{*}$ & 9954 \\
H. commersoni vs. H. hermanni & 1.383 & 0.1003 & 9946 \\
H. commersoni vs. Hypostomus sp. & 3.672 & $0.0001^{*}$ & 9945 \\
H. commersoni vs. H. stigatriceps & 0.911 & 0.5305 & 9954 \\
H. hermanni vs. Hypostomus sp. & 3.149 & $0.0001^{*}$ & 9942 \\
H. hermanni vs. H. stigatriceps & 1.319 & 0.1445 & 9959 \\
Hypostomus sp. vs. H. stigatriceps & 1.952 & $0.0031^{*}$ & 9955 \\
\hline \multicolumn{1}{c}{ Species vs. Seasons } & & & 9959 \\
\hline H. ancistroides (Rainy vs. Dry) & 1.799 & $0.0004^{*}$ & 9948 \\
H. commersoni (Rainy vs. Dry) & 0.758 & 0.7145 & 9897 \\
H. hermanni (Rainy vs. Dry) & 1.064 & 0.3623 & 9954 \\
Hypostomus sp. (Rainy vs. Dry) & 1.889 & $0.0049^{*}$ & 8323 \\
H. stigatriceps (Rainy vs. Dry) & 1.384 & $0.0963^{*}$ & \\
\hline
\end{tabular}

the diets of Hypostomus sp. and H. ancistroides, H. commersoni, $H$. hermanni and $H$. stigatriceps resulted from the variable percentage contributions of filamentous algae, Chlorophyceae, Cyanophyceae, Euglena species, free-living nematodes, insects remains, and testate amoebae. Those items also contributed to the overall dissimilarity between the dry and rainy seasons for $H$. ancistroides, Hypostomus sp. and H. stigatriceps (Table 5).

The Ecosim analyses of dietary overlap based on Pianka's index found high values (>90\%) for all pairs of species, indicating substantial similarity in the diets of Hypostomus species in both seasons (Table 6). Comparisons with null (RA3) models indicated that the observed overlap between species in dry (0.96) and rainy (0.99) seasons was greater than expected by chance $(0.16, \mathrm{p}=0.001)$.

\section{DISCUSSION}

All five species of Hypostomus were sampled along the main channel of the Corumbataí River, in the dry and rainy seasons. The relatively high species richness and abundance of representatives of this genus can be explained by the great amount of fast-flowing aquatic environments and rocky substrate, environments that favor the occurrence of armored catfish (WeBer 2003), in addition to many illuminated stretches with submerged streamside vegetation, where loricariids display a surface-grazing foraging behaviour (MONTOYA-BuRgos et al. 2003, LuJAN et al. 2012).

Food items ingested by Hypostomus species in the Corumbataí River indicate that these suckermouth loricariids are bottom-dwelling detritivorous/periphytivorous catfishes. The large and diverse number of food items registered in the diet of Hypostomus species, in our data, with a predominance of detritus and periphyton, was expected (e.g., CASATTI 2002, CASATTI et al.
Table 5. Percentage contribution of food items to the average similarity percentages (AS) in the diets of Hypostomus species' in the dry and rainy seasons, obtained with SIMPER analysis. Items' contributions that cumulatively summed up to $\sim 97 \%$ are shown. (DEB) Detritus, (DIA) Diatoms, (FRA) Algae fragments, (CIA) Cyanophyceae, (FIL) Filamentous algae, (CLF) Chlorophyceae, (EUG) Euglena spp., (FGI) Insect remains, (NEM) Free-living nematodes, (TCM) Testate amoebae, (ZYG) Zygnematophyceae.

\begin{tabular}{|c|c|c|c|c|c|c|c|c|c|c|}
\hline \multirow{2}{*}{$\frac{\text { Species }}{\text { Season }}$} & \multicolumn{2}{|c|}{ H. ancistroides } & \multicolumn{2}{|c|}{ H. commersoni } & \multicolumn{2}{|c|}{ H. hermanni } & \multicolumn{2}{|c|}{ Hypostomus sp. } & \multicolumn{2}{|c|}{ H. stigatriceps } \\
\hline & Dry & Rainy & Dry & Rainy & Dry & Rainy & Dry & Rainy & Dry & Rainy \\
\hline AS (\%) & 72.2 & 72.4 & 75.9 & 73.7 & 76.7 & 75.5 & 75.7 & 79.6 & 75.9 & 79.4 \\
\hline DEB & 31.4 & 34.1 & 29.3 & 29.4 & 29.5 & 31.3 & 25.9 & 23.8 & 27.1 & 30.3 \\
\hline DIA & 30.1 & 26.9 & 26.5 & 26.2 & 26.4 & 21.8 & 25.3 & 21.8 & 25.7 & 23.7 \\
\hline FRA & 22.8 & 31.8 & 28.1 & 27.1 & 27.3 & 29.7 & 24.7 & 22.5 & 24.5 & 28.4 \\
\hline $\mathrm{CIA}$ & 5.54 & 0.57 & 2.33 & 3.67 & 5.66 & 5.21 & 5.64 & 5.23 & 1.22 & 5.36 \\
\hline FIL & 3.11 & $<0.01$ & 5.03 & 5.44 & 1.53 & 4.01 & 9.03 & 14.2 & 9.56 & 4.69 \\
\hline $\mathrm{CLF}$ & 3.52 & 0.39 & 6.33 & 4.90 & 6.14 & 5.82 & 4.12 & 6.77 & 7.95 & 7.09 \\
\hline EUG & 0.22 & 2.37 & 0.75 & 1.20 & 0.71 & 0.16 & 2.27 & 2.84 & 0.79 & $<0.01$ \\
\hline $\mathrm{FGI}$ & 0.56 & 2.43 & 0.22 & 0.21 & $<0.01$ & 0.78 & 0.16 & 0.01 & 0.21 & $<0.01$ \\
\hline NEM & 0.44 & 0.42 & 0.63 & 0.61 & 0.83 & 1.16 & 0.98 & 0.34 & $<0.01$ & $<0.01$ \\
\hline TCM & 0.26 & - & 0.17 & 0.18 & - & - & 0.34 & 0.06 & 0.40 & - \\
\hline ZYG & - & 0.28 & - & 0.01 & - & - & 0.06 & - & - & - \\
\hline
\end{tabular}

Table 6. Interspecific diet overlap (Pianka's index) among Hypostomus species in each season.

\begin{tabular}{lclll}
\hline & \multicolumn{2}{c}{ Species } & \multicolumn{2}{c}{ Pianka's index } \\
\cline { 3 - 5 } & & Dry & Rainy \\
\hline H. ancistroides & vs. & H. commersoni & 0.94 & 0.99 \\
H. ancistroides & vs. & H. hermanni & 0.92 & 0.98 \\
H. ancistroides & vs. & Hypostomus sp. & 0.98 & 0.98 \\
H. ancistroides & vs. & H. stigatriceps & 0.96 & 0.99 \\
H. commersoni & vs. & H. hermanni & 0.98 & 0.99 \\
H. commersoni & vs. & Hypostomus sp. & 0.98 & 0.99 \\
H. commersoni & vs. & H. stigatriceps & 0.99 & 0.99 \\
H. hermanni & vs. & Hypostomus sp. & 0.96 & 0.97 \\
H. hermanni & vs. & H. stigatriceps & 0.97 & 0.98 \\
Hypostomus sp. & vs. & H. stigatriceps & 0.99 & 0.99 \\
\hline
\end{tabular}

2009, Cardone et al. 2006, Delariva \& Agostinho 2001, Gomiero \& Braga 2008, Meschiatti \& Arcifa 2009). Detritus is a protein-rich organic material, and there is a large number of micro and macro organisms associated with the degradation processes of this material (FAusch et al. 2002, FlecKer et al. 2002, McInTyre et al. 2007). Periphyton is a complex community of algae, bacteria, fungi, protozoa, micro crustaceans, organic and inorganic material adhered to, or associated with, the substrate (JACOBSEN 2008).

The foraging patterns showed evidence of resource sharing in the dry and rainy periods, as observed values of niche overlap were higher than those expected by chance. The high consumption of detritus and also autochthonous items such as algae and aquatic immature insects seems to explain the feeding overlap, and probably reflect their high availability in the aquatic environment, allowing the coexistence of these catfishes. The high degree of niche overlap was already registered among de- 
tritivorous Hypostomus (e.g., Oliveira \& IsaAc 2013, Villares-Junior et al. 2016), and this feeding strategy requires complex anatomical-physiological adaptations in order to exploit detritus (BoweN 1983). The suckermouth-scraping feeding mechanism (SCHAEFER \& LAUDER 1986) and the long and coiled digestive tract (DELARIVA \& Agostinho 2001) are remarkable functional traits that are essential for the success of loricariids in exploiting detritus and associated items (Delariva \& Agostinho 2001, Lujan et al. 2012).

Our analyses also indicate variation in the consumption of some resources among Hypostomus species and seasons, and the contribution of periphytic algae was primarily responsible for such dissimilarity. Differences in periphyton composition, for example, depend on several environmental characteristics, such as the type of substrate (CATTANEO et al. 1997), level of disturbance (Biggs et al. 1998), hydrodynamics (AlgarTe et al. 2009), nutrient availability (Moulton et al. 2010), light (Hill 1996), and biological control by grazing (Rosemond et al. 1993), affecting the availability of this resource and consequently feeding overlap. In addition, factors such an increase in the sediment carried by rains increase the accumulation of particulate matter on periphyton, with a consequent reduction in photosynthetic biomass and in the diversity and density of organisms (e.g. algae, Verceluino \& Bicudo 2006), with the opposite effect in the dry season (Felisberto \& Rodrigues 2005, Jacobsen 2008, Martins \& Fernandes 2011).

Variations in resource utilization among Hypostomus species can be also explained by differences in how the species use their foraging habitats. These differences, in part, result from the different attachment mechanisms they display. These attachment mechanisms ensure that the individuals can maintain their position [while feeding] and result in the differential occupation of lotic systems by the various species (Buck \& Sazima 1995, Garavello \& Garavello 2004, Pagotto et al. 2011). In addition, the differences in the morphology and functional versatility (SCHAEFer \& LAUDER 1986, LUJAN \& ARMBRUSTER 2012) of the ventrally oriented feeding apparatus, which bear teeth that touch the substrate from which algae and other food items are scraped, are also relevant to resource partitioning, since these morphological differences result in different ways of obtaining food (Delariva \& Agostinho 2001).

In summary, our data show that trophic resources available in the Corumbataí River are shared among five morphologically similar Hypostomus species, all specialized in surface-grazing foraging behaviour. The food resource partitioning between loricariid species may be interpreted as an adaptive response that results in a greater exploitation of the available resources, and differences in the diet between coexisting similar species are probably associated with morphological peculiarities of the feeding apparatus of each species.

\section{ACKNOWLEDGEMENTS}

We thank Claudio Zawadzki (State University of Maringá) for helping with the identification of Hypostomus species; GPIc (Grupo de Pesquisas em Ictiofauna, MHNCI) and the Phycology
Lab of the Federal University of Paraná for their help with the analyses and the identification of food items; Coordenação de Aperfeiçoamento de Pessoal de Nível Superior (CAPES) MSc fellowship to MOV. JRSV is thankful to the Brazilian Council of Research (Conselho Nacional de Desenvolvimento Científico e Tecnológico - CNPq) for the continuous funding through a Research Productivity Grant. Samples were collected in accordance with Brazilian environmental protection legislation (Permission MMA/IBAMA/SISBIO \#10320-1) in compliance with the National Council of Animal Experimentation (CONCEA) norms.

\section{LITERATURE CITED}

Algarte VM, Siqueira NS, Muramaki EA, Rodrigues L (2009) Effects of hydrological regime and connectivity on the interannual variation in taxonomic similarity of periphytic algae. Brazilian Journal of Biology 69: 609-616. doi: 10.1590/S151969842009000300015

Anderson MJ, Gorley RN, Clarke KR (2008) PERMANOVA + for Primer: Guide to Software and Statistical Methods. Plymouth, Primer-E, 214p.

Aranha JMR (1993) Método para análise quantitativa de algas e outros itens microscópicos de alimentação de peixes. Acta Biologica Paranaense 22: 71-76. doi: 10.5380/abpr.v22i0.724

Biggs JF, Stevenson RJ, Lowe RL (1998) A habitat matrix conceptual model for stream periphyton. Archiv für Hydrobiologie 143: 21-56.

Bowen SH (1983) Detrivory in neotropical fish communities. Environmental Biology of Fishes 9: 137-144. doi: 10.1007/ BF00690858

Buck S, SAZIMA I (1995) An assemblage of mailed catfishes (Loricariidae) in southeastern Brazil: distribution, activity, and feeding. Ichthyological Exploration of Freshwaters 6: 325-332.

BuRgESS WE (1989) An atlas of freshwater and marine catfishes. A preliminary survey of the Siluriformes. New Jersey, T.F.H. Publications, 784p.

Cardone IB, Lima-Junior SE, Goitein R (2006) Diet and capture of Hypostomus strigaticeps (Siluriformes, Loricariidae) in a small Brazilian stream: relationship with limnological aspects. Brazilian Journal of Biology 66: 25-33. doi: 10.1590/S151969842006000100005

Casatti, L (2002) Alimentação dos peixes em um riacho do Parque Estadual Morro do Diabo, bacia do Alto Rio Paraná, sudeste do Brasil. Biota Neotropica 2: 1-14. doi: 10.1590/ S1676-06032002000200012.

Casatti L, Castro RMC (2006) Testing the ecomorphological hypothesis in a headwater riffles fish assemblage of the São Francisco River, southeastern Brazil. Neotropical Ichthyology 4: 203-214. doi: 10.1590/S1679-62252006000200006

Casatti L, Ferreira CP, Carvalho FR (2009) Grass-dominated stream sites exhibit low fish species diversity and dominance by guppies: an assessment of two tropical pasture river basins. Hydrobiologia 632: 273-283. doi: 10.1007/s10750-009-9849-y 
Cattaneo A, Kerimian T, Roberge M, Marty J (1997) Periphyton distribution and abundance on substrata of different size along a gradient of stream trophy. Hydrobiologia 354: 101110. doi: 10.1023/A:1003027927600

Caviglione JH, Kinhl LRB, Caramori PH, Oliveira D (2000). Cartas climáticas do Paraná. Londrina, Instituto Agronômico do Estado do Paraná.

Clarke KR, Gorley RN (2006) PRIMER v. 5: User manual/tutorial. Plymouth, PRIMER-E, 91p.

Delariva RL, Agostinho AA (2001) Relationship between morphology and diets of six Neotropical loricariids. Journal of Fish Biology 58: 832-847. doi: 10.1111/j.1095-8649.2001. tb00534.x

Dudgeon D (1993) The effects of spate-induced disturbance, predation and environmental complexity on macroinvertebrates in a tropical stream. Freshwater Biology 30: 189-197. doi: 10.1111/j.1365-2427.1993.tb00801.x

Fausch KD, Torgersen CE, BaXter CV, Li HW (2002) Landscapes to riverscapes: bridging the gap between research and conservation of stream fishes. BioScience 52: 483-498. doi: 10.1641/0006-3568(2002)052[0483:LTRBTG]2.0.CO;2

Felisberto SA, Rodrigues L (2005) Influência do gradiente longitudinal (rio-barragem) na similaridade das comunidades de desmídias perifíticas. Brazilian Journal of Botany 28: 241254. doi: 10.1590/S0100-84042005000200005

FerReIra KM (2007) Biology and ecomorphology of stream fishes from the Mogi-Guaçu River basin, southeastern Brazil. Neotropical Ichthyology 5: 311-326. doi: 10.1590/S167962252007000300012

Flecker AS, Taylor BW, Bernhardt ES, Hood JM, Cornwell WK, Cassat SR, Vanni MJ, Altman NS (2002) Interactions between herbivorous fishes and limiting nutrients in a tropical stream ecosystem. Ecology 83: 1831-1844. doi: 10.1890/0012-9658(2002)083[1831:IBHFAL]2.0.CO;2

Frehse FA, Valduga MO, Corrêa MFM, Pinheiros PC, Vitule JRS (2015) Feeding ecology and resource sharing patterns between Stellifer rastrifer (Jordan, 1889) and S. brasiliensis (Schultz, 1945) (Perciformes: Sciaenidae) along the coasts of Paraná and Santa Catarina, Brazil. Journal of Applied Ichthyology 1: 1-8. doi: 10.1111/jai.12768

Garavello JC, Garavello JP (2004) Spatial distribution and interaction of four species of the catfish genus Hypostomus Lacépède with bottom of São Francisco River, Canindé do São Francisco, Sergipe, Brazil (Pisces, Loricariidae, Hypostominae). Brazilian Journal of Biology 64: 591-598. doi: 10.1590/S1519-69842004000400006

Gomiero LM, Braga FMS (2008) Feeding habits of the ichthyofauna in a protected area in the State of São Paulo, south-eastern Brazil. Biota Neotropica 8: 41-47. doi: 10.1590/S167606032008000100004

Gotelli NJ, ENTSMINGer GL (2000) EcoSim: Null models software for ecology. Version 5.0. Acquired Intelligence Inc. and Kesey-Bear. Available online at: http://homepages.together. net/ gentsmin/ecosim.htm [Accessed 20/07/2016]

Gotelli NJ, Hart EM, Ellison AM (2015) EcoSimR: null model analysis for ecological data. $\mathrm{R}$ package version 0.1.0. Available online at: http://github.com/gotellilab/EcoSimR [Accessed 20/07/2016]

Hill WR (1996) Effects of light, p. 121-148. In: STEvenson RJ, Bothwell ML, Lowe RL (Eds.) Algal ecology: freshwater bentic ecosystems. New York, Academic Press.

HyNEs HBN (1950) The food of fresh-water Sticklebacks (Gasterosteus aculeatus and Pygosteus pungitius), with a review of methods used in studies of the food of fishes. Journal of Animal and Ecology 19: 36-58. doi: 10.2307/1570

IAPAR (2015) Desvios de precipitação e temperatura. Londrina, Instituto Agronômico do Estado do Paraná. Available online at: http://www.iapar.br/modules/conteudo/conteudo.php?conteudo $=984$ [Accessed 23/10/2015]

JACOBSEN D (2008) Tropical high-altitude streams, p. 219-256. In: Dudgeon D (Ed.) Tropical stream ecology. San Diego, Academic Press.

Jepsen DB, Winemiller KO, TAPHoRn DC (1997) Temporal patterns of resource partitioning among Cichla species in a Venezuelan blackwater river. Journal of Fish Biology 51: 1085-1108. doi: 10.1111/j.1095-8649.1997.tb01129.x

Langeani F, Castro RMC, Oyakana OT, Shibatta OA, Pavanelli CS, CasatTi L (2007) Diversidade da ictiofauna do Alto Rio Paraná: composição atual e perspectivas futuras. Biota Neotropica 7: 1-17. doi: 10.1590/S1676-06032007000300020

Lujan NK, Armbruster JW (2012) Morphological and functional diversity of the mandible in suckermouth armored catfishes (Siluriformes: Loricariidae). Journal of Morphology 273: 24-39. doi: 10.1002/jmor.11003

LujAn NK, Winemiller K, Armbruster JW (2012) Trophic diversity in the evolution and community assembly of loricariid catfishes. BMC Evolutionary Biology 12: 124. doi: 10.1186/1471-2148-12-124 Martins FCO, Fernandes VO (2011) Biomassa e composição elementar (C, N e P) da comunidade perifítica em diferentes gradientes fluviais tropical (alto rio Santa Maria da Vitória, Espírito Santo, Brasil). Brazilian Journal of Aquatic Science and Technology 15: 11-18. doi: 10.14210/bjast.2011v15n1

Mazzoni R, Moraes M, Rezende CF, Miranda JC (2010) Alimentação e padrões ecomorfológicos das espécies de peixes de riacho do alto rio Tocantins, Goiás, Brasil. Iheringia, Série Zoologia, 100: 162-168. doi: 10.1590/S0073-47212010000200012 McIntyre PB, Jones LE, Flecker AS, Vanni MJ (2007) Fish extinctions alter nutrient recycling in tropical freshwaters. Proceedings of the National Academy of Sciences USA 104: 4461-4466. doi: 10.1073/pnas.0608148104

Merona B DE, RankIN-DE-Merona J (2004) Food resource partitioning in a fish community of the central Amazon floodplain. Neotropical Ichthyology 2: 75-84. doi: 10.1590/S1679-62252004000200004

Meschiatti AJ, Arcifa MS (2009) A review on the fish fauna of Mogi-Guaçu River basin: a century of studies. Acta Limnologica Brasiliensis 21: 135-159. 
Montoya-Burgos Ji, Marinho MMF, Langeani F, Serra JP (2003) Historical biogeography of the catfish genus Hypostomus (Siluriformes: Loricariidae), with implications on the diversification of Neotropical ichthyofauna. Molecular Ecology 12: 1855-1867. doi: 10.1046/j.1365-294X.2003.01857.x

Moulton TP, Souza ML, Silveira RML, Krsulovic FAM, Silveira MP, Assis JCF, Francischetti CN (2010) Patterns of periphyton are determined by cascading trophic relationships in two neotropical streams. Marine and Freshwater Research 61: 57-64. doi: 10.1071/MF08326

Oliveira JCS, IsaAc VJ (2013) Diet breadth and niche overlap between Hypostomus plecostomus (Linnaeus, 1758) and $\mathrm{Hy}$ postomus emarginatus (Valenciennes, 1840) (Siluriformes) in the Coaracy Nunes hydroelectric reservoir, Ferreira Gomes, Amapá-Brazil. Biota Amazonia 3: 116-125. doi: 10.18561/2179-5746/biotaamazonia.v3n2p116-125

Pagotto JPA, Goulart E, Oliveira EF, Yamamura CB (2011) Trophic ecomorphology of Siluriformes (Pisces, Osteichthyes) from a tropical stream. Brazilian Journal of Biology 71: 469-479. doi: 10.1590/S1519-69842011000300017

PIANKa ER (1973) The structure of lizard communities. Annual Review of Ecology and Systematics 4: 53-74.

Podkowa D, GoniakowsKa-WitalińsKa L (2003) Morphology of the air-breathing stomach of the catfish Hypostomus plecostomus. Journal of Morphology 257: 147-163. doi: 10.1002/ jmor. 10102

POWER ME (1984) Depth distributions of armoured catfish: predator-induced resource avoidance? Ecology 65: 523-528. doi: $10.2307 / 1941414$

Rosemond AD, Mulholland PJ, Elwood JW (1993) Top-Down and bottom-up control of stream periphyton: effects of nutrients and herbivores. Ecology 74: 1264-1280. doi: $10.2307 / 1940495$

Ross ST (1986) Resource partitioning in fish assemblages: a review of field studies. Copeia 2: 352-388. doi: 10.2307/1444996

R Development Core Team (2016). R: A language and environment for statistical computing. Vienna, The R Project for Statistical Computing. Available online at: http://www.r-project.org [Accessed 20/07/2016]

Schaefer SA, LAuder G (1986) Historical transformation of functional design: evolutionary morphology of feeding mechanisms in loricariid catfishes. Systematic Zoology 35: 489-508. doi: 10.2307/2413111

SCHAEFER SA (1987) Osteology of Hypostomus plecostomus (Linnaeus) with a phylogenetic analysis of the loricariid subfamilies
(Pisces: Siluroidei). Contributions in Science 394: 1-31.

Schoener TW (1974) Resource partitioning in ecological communities. Science 185: 27-39. doi: 10.1126/SCIENCE.185.4145.27

Silva JC da, Delariva RL, Bonato KO (2012) Food-resource partitioning among fish species from a first-order stream in northwestern Paraná, Brazil. Neotropical Ichthyology 10: 389-399. doi: 10.1590/S1679-62252012005000008

Vercellino IS, Bicudo DC (2006) Periphytic algae community succession in a tropical oligotrophic reservoir (São Paulo, Brazil): comparison between dry and rainy season. Revista Brasileira de Botânica 29: 363-377. doi: 10.1590/S010084042006000300004

Villares-Junior GA, Cardone IB, Goitein R (2016) Comparative feeding ecology of four syntopic Hypostomus species in a Brazilian southeastern river. Brazilian Journal of Biology 76: 692-699. doi: 10.1590/1519-6984.00915.

WALLACE JR RK (1981) An assessment of diet overlap indexes. Transactions of the American Fisheries Society 110: 7276. doi: 10.1577/1548-8659(1981)110<72:AAODI>2.0.CO;2

Weber C (2003) The Hypostominae, p. 351-372. In: ReIs RE, Kullander SO, Ferraris Jr CJ (Eds.) Check list of the freshwater fishes of South and Central America. Porto Alegre, Edipucrs, 729p.

Winemiller KO (1989) Ontogenetic diet shifts and resource partitioning among piscivorous fishes in the Venezuelan llanos. Environmental Biology of Fishes 26: 177-199. doi: 10.1007/BF00004815

Winemiller KO, Agostinho AA, Caramaschi PE (2008) Fish ecology in tropical streams, p. 336-346. In: Dudgeon D (Ed.) Tropical stream ecology. San Diego, Academic Press.

Submitted: 6 April 2016

Received in revised form: 21 September 2016

Accepted: 2 October 2016

Editorial responsibility: Cassiano Monteiro Neto

Author Contributions: VA, MOV and JRSV conceived and designed the study; VA, MOV, FAF and JRSV analyzed the data and wrote the paper.

Competing Interests: The authors have declared that no competing interests exist. 